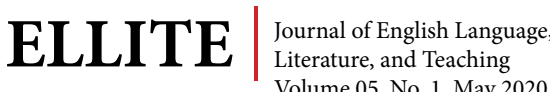

\section{Reading Intensity on Students' Speaking Ability}

Fitrotul Mufaridah \& Siti Lutfiyah

Universitas Muhammadiyah Jember, Indonesia

(mufaridah@unmuhjember.ac.id)

\begin{abstract}
Speaking as a language skill has been considered the most difficult one to master by the students especially in Songserm Wittaya School Songkla, Thailand. It was found that the majority of the students found it difficult to speak English fluently. As a productive skill, speaking is complex because learners need to acquire the accuracy and fluency in speaking. However, one EFL class showed a bit difference in the ability of speaking English because of their reading intensity. The design of the research was descriptive qualitative because the study aimed to explore how the reading intensify affect their speaking. The data were collected by a questionnaire for intensive reading and an interview on speaking to 30 students at $4 / 3$ grade. The results of this research in general revealed that most of the students at grade 4/3 Thailand are good in speaking English due to their intensive reading that reached $50 \%$. It was clearly seen from the analysis of some aspects of speaking (pronunciation, grammar, vocabulary, fluency and comprehension) in the interview section and questionnaire of reading intensity that $50 \%$ of the participants can speak English better through reading activity intensively. This finding implies that intensive reading has become a meaningful input for students' speech production.
\end{abstract}

Keywords: Speaking ability; intensive reading; reading intensity; speaking aspect.

English language teaching has been conducted in Thailand for more than a century. It started in the reign of King Rama III (1824 -1851) by an American missionary (Darasawang, 2007). Although English has been taught in Thailand for more than a century, speaking in English remains a serious problem for most of the students. In general, Thai's level of English proficiency is lowest in comparison to other countries in Asia such as Malaysia, Philippines, and Singapore (Wiriyachitra, 2002).

Mastering speaking is not easy particularly for students in Songserm Wittaya School Songkla, Thailand. It was really difficult for the students to answer an easy question such as "what are you doing?" Through a simple observation, it was known that the 
students knew what to answer but could not find a word to do so. It was assumed that the difficulty was a result of the lack of vocabulary. Meanwhile, through the observation it was also known that there was a little bit difference in class $4 / 3$. The students could speak English a little bit better than their counterparts in the other class.

In language teaching and learning, speaking is considered a skill to practice and master. In this light, speaking as a productive skill, it consists of producing systematic verbal utterance to convey meaning (Nunan, 1991). Additionally, speaking is an interactive process of constructing meaning that involves producing and receiving processed information. Therefore, this is a skill that dominates much part of one's life that people take for granted (Thornbury, 2005).

Despite its massive role in daily life, speaking ability is still a matter which needs much effort. No matter how great an idea is, if it is not communicated properly, it cannot be effective. To speak English well and casual, the students obviously have to try to speak it in the way the native speakers do, especially how their language is understandable to the listeners.

According to Brown (2000:268), there are two aspects of speaking skill; they are accuracy and fluency. The former means that the speakers are required to speak using correct vocabulary in accurately-structured sentences and make utterances in accurate pronunciation. While fluency means that the speakers are required to be able to keep going when speaking spontaneously with minimum pauses.

This research was looking at how reading intensity is effective on students' speaking ability at $4 / 3$ grade in Songserm Wittaya School Songkla-Thailand. According to Algozaly and Ahmed (2015) intensive reading can greatly improve and reinforce students' speaking skill. This is obvious when they grasp the meaning of reading text, that is to say the idiomatic expressions and phrasal verbs which we formed in the written text can also be expressed in the oral communication. Moreover, they assured that intensive reading increases students' command of necessary vocabulary and enable them to develop the oral communication.

According to Brown (2000: 312), intensive reading calls students' attention to grammatical forms, discourse markers, and other surface structure details for the purpose of understanding literal meaning, implications, rhetorical relationship, and the like.

However, there are further roles teachers need to adopt when asking students to read intensively, those are organizer, observer, feedback organizer and prompter, (Algozaly and Ahmed, 2015). The following paragprahs will describe each role.

\section{a. Organizer}

Organizer here means the teachers need to tell students what their reading purpose is, and give those clear instructions about how to achieve it, and how long they have to do this. Being an organizer is important when the student readers are not yet independent, therefore a teacher as an organizer will show them how it is done.

\section{b. Observer}

Observer means here is when teachers ask students to read on their own while providing them enough space to do so. This means teachers should restrain themselves from interrupting that reading process, even though there will be temptation to add more information or instructions. Instead, teachers can observe their reading progress since this will give them valuable information about how well they are doing individually and collectively, and will inform teachers whether to give them some extra time or, move to organizing feedback more quickly than teachers had anticipated. 
c. Feedback organizer

When students have completed the task, teachers can lead a feedback session to check that they have completed the task successfully. Teachers may start by having them compared their answers in pairs and ask for answers from the class in general or from pairs in particular. Students often appreciate giving paired answers like this since, by sharing their knowledge, they are also sharing their responsibility for the answers.

It is important to be supportive when organizing feedback after reading if teachers are to counter any negative feelings students might have about the process and if teachers wish to sustain their motivation. Reading, at the end, should leave the students feeling of contentment, not frustration.

\section{d. Prompter}

When students have read a text teachers can prompt them to notice language features in that text. It applies when teachers use reading as an activity to allow students find language features, or other learning material, in use. Teachers may also, as controllers, direct them to certain features of text construction, clarifying ambiguities, and making them aware of issues of text structure which they had not come across previously (Harmer, 2001, pp 210-213). This will arise their awareness of features in texts.

\section{Method}

The research design was descriptive qualitative research. According to Arikunto (2013:3) descriptive research is designed to reveal the current status of a phenomenon and directed toward the time of the study and to describe what actually exists.

The subject of this research is the students of Songserm Wittaya School Songkla Thailand, especially in $4 / 3$ grade. There are 30 students, consisting of 26 females and 4 males.

There were two instruments used to collect the data. Interview was designed for collecting students' speaking ability, and the questionnaire was designed for collecting students' reading intensity. For analysis speaking score an instrument adopted from Hughes was used (Hughes, 2003, pp. 131-132), while multiple choice questions were given for identifying students' reading intensity.

\section{Results and Discussion}

The questionnaire of students' reading intensity showed that the option of students who love reading an English book was higher than the other option, $56.7 \%$ or 17 respondents. The second option was "Like it" reached 9 (30\%) respondents. In the third option was "somehow like it" $13.3 \%$ or 4 respondents, and no one said dislike read an English book. The result of analysis is presented in Table 1.

The questionnaire is also used to find the kind of English books that students in $4 / 3$ grade usually read. The answer to this is displayed in Table 2.

The data showed that an English comic was the favorite one, $60.0 \%$ from 18 respondents. Neuroscientific research by Berns, ed. (2013) indicates that reading stories actually has a noticeable effect on brain function. In reading comic books children are engaging with highly complex and structured narrative forms. Whether they realize it or not, their emergent visual literacy promotes thinking skills and develops wider met

Table 1. Students' Activity in Reading English Book

Do you like read an English book?

\begin{tabular}{llll}
\hline No & Options & Frequency & Percentage \\
\hline 1. & Love it & 17 & $56.7 \%$ \\
2. & Like it & 9 & $30 \%$ \\
3. & $\begin{array}{l}\text { Somehow } \\
\text { like it }\end{array}$ & 4 & $13.3 \%$ \\
4. & Dislike it & 0 & 0 \\
\hline \multicolumn{2}{l}{ Total } & 30 & $100 \%$ \\
\hline
\end{tabular}


Table 4. Student's Understanding of an English Text

Table 2. Kinds of English Texts Read

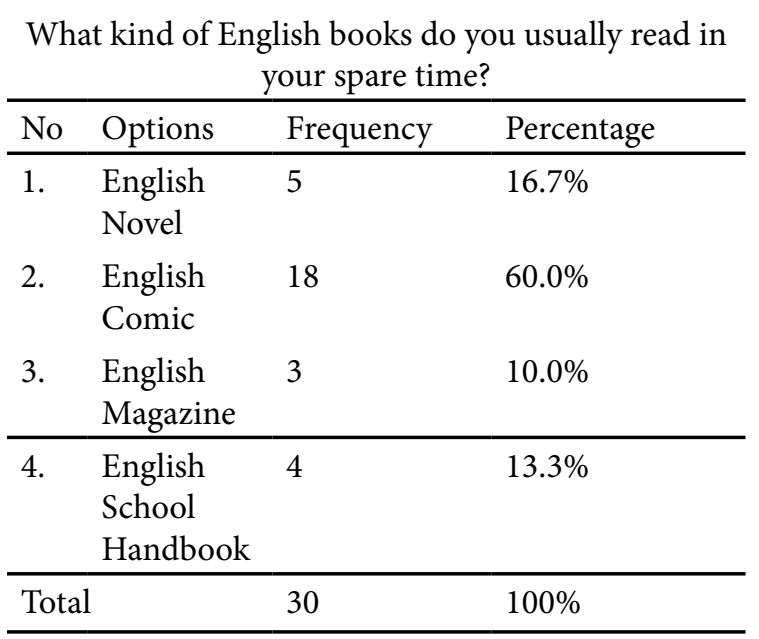

Table 3. Time Spent to Read an English Book

How long do you usually read that English book?

\begin{tabular}{llll}
\hline No & Options & Frequency & Percentage \\
1. & $\begin{array}{l}\text { Less than } \\
\text { an hour }\end{array}$ & 2 & $6.7 \%$ \\
2. An hour & 3 & $10.0 \%$ \\
3. More than & 8 & $26.7 \%$ \\
& $\begin{array}{l}\text { an hour } \\
\text { 4. As I like }\end{array}$ & 17 & $56.7 \%$ \\
Total & 30 & $100 \%$ \\
\hline
\end{tabular}

cognitive abilities. This study showed how reading a compelling comic changed participants' neuron activity not only while they were reading but also for several days after they finished the comic that was assigned to them.

The questionnaire was also search about the length of students' reading activity. The data is shown in Table 3. Based on the result, "as I like" answer was the highest one; 17 respondents (56.7\%). The respondents like to read an English book as the way they want. From the answer that the research got, some of the participants said than they had anything else that should they do. Reading was just only one of their hobbies. There are some disadvantages of too much reading.
When you read a text in English, can you understand it?

\begin{tabular}{llll}
\hline No & Options & $\begin{array}{l}\text { Frequen- } \\
\text { cy }\end{array}$ & $\begin{array}{l}\text { Percent- } \\
\text { age }\end{array}$ \\
\hline 1. & $\begin{array}{l}\text { Yes. It is not a } \\
\text { problem at all }\end{array}$ & 0 & 0 \\
2. $\quad \begin{array}{l}\text { I can understand } \\
\text { it most of the time }\end{array}$ & 11 & $36.7 \%$ \\
3. $\quad \begin{array}{l}\text { I can understand } \\
\text { it sometimes, but } \\
\text { it is still a problem } \\
\text { at other times } \\
\text { I can hardly un- } \\
\text { derstand it. }\end{array}$ & 0 & $6.3 .3 \%$ \\
Total & 30 & 0 \\
\hline
\end{tabular}

For instance, when people spend a lot of time reading books, their eyesight will become myopic, which is another word nearsightedness. Second, people who spend a lot of time reading books will cause them more likely to be antisocial, which is one of the biggest issues for some people. Last, I would think too much reading will cause behavioral and mental problem, which cause some people to easily forget things and don't really care about what's going on in their surroundings.

The questionnaire also recorded students' understanding in reading. They tried to learn new words when they read. However, sometimes they did not understand their meanings. From 30 respondents, 19 (63.3\%) respondents said that they sometimes did not understand the story or information but sometimes they did, and 11 (36.7\%) respondents said that they usually understand the meaning of the story. The data can be seen in Table 4.

When they did not understand the meaning, they also need a dictionary to get the meaning. It can be seen that they really want to know the meaning. From 30 respondents, $17(56.7 \%)$ respondents said that they always use dictionary when they did not understand the meaning. From the study, it was found 
that $56.7 \%$ of them revealed that they always look up the dictionary while reading. It could be assumed that despite the hard work of understanding the text, the students still want to read.

More quetion was about their way in understanding meaning. 30 respondents, $17(56.7 \%)$ respondents said that they always tried to guess the main ideas of the text on the basis of pictures. They tried to find the meaning by looking at the picture, charts or figures that already have been there. The picture, charts or figures that had been printed in some stories had its meaning. The student would understand easily when they look at the picture; charts or figures before they started read the text. This is a useful reading strategy that any EFL students can apply.

The last question was about their feeling when they read an English book. One person (3.3\%) said that she loved read an English book, 16(53.3\%) said that they liked read an English book, 13(43.3\%) said that they little a bit liked read an English book and no one dislike reading an English book. This is a good sign of maintaining the reading activity.

Reading a book could help the students find new words. Just by reading and understanding its meaning from the context, the student can build quite a large passive English vocabulary. The student can use that new vocabulary while speaking English. To achieve that, the students should have to practice speaking English with others, so that they can develop natural ability to speak effortlessly and fluently.

In speaking analysis there are five aspect that the researcher used to find speaking score, there were accent, vocabulary, grammar, fluency, and comprehension. Every aspect there is 6 points. The higher will get 6 rating score will the lower will get 0 rating score. The research told that there were two students got 4 rating score, thirteen students got 3 rating score, three students got $3+$ rating score, four students got 2 rating score, and eight students got $2+$ rating score.
Speaking has five aspects that really important, those are accent, grammar, vocabulary, fluency and comprehension. In this researcher, it was found that $86 \%$ of students in Sonnserm Wittaya in 4/3 grade love and like read an English book and 60\% of student said that an English comic is the favorite one. This is obvious when the student read an English comic they grasp the meaning of a reading text, that is to say, the idiomatic expressions and phrasal verbs which formed in the written text. It can also be expressed in the oral communication. Moreover, intensive reading increases students' command of vocabulary which they need and enable them to develop the oral communication. If they do not understand the meaning, they also used a dictionary to help them. It could be seen from their reading questionnaire that $56.7 \%$ of student in $4 / 3$ grade use dictionary to find the meaning.

When we talk about accent in that class, they have similar accent in speaking English. In this case, the students are difficult in pronouncing English word. They are trying to speak English face the same roadblocks. According to Ackrapong (2009) some sounds are difficult for Thai learners to produce. Every student often confuses the lateral alveolar approximant / / with the alveolar approximant $/ r /$. When they pronounce ' $L$ ', they will say 'ew', the letter W has a V sound like the word 'when' become 'Ven' and there is no TH sound in their language. There's no audible difference between R's and L's. Rabbit is pronounced, Labbit. Leader is pronounced, Reader. The words 'flute' and 'fruit' sound the exact same to Thai student. According to Khamkhien (2010) most of the Thai learners did not possess satisfactory competence in English pronunciation. Although one of them is not really good in accent, they still can answer what the researcher asked in interview section.

When students read an English book intensively, they not only find the meaning but also see the structure of the grammar. However, only few of them use it. Students in Songserm 
Wittaya School are the creative one. They like doing handicrafts. Every walls of their class full of the picture of their handicraft which is hang on the wall. One of the interesting handicrafts is part of grammar pattern but it is just hanging on the wall, never use it. They know about grammar and they memorize it. They memorize the entire pattern, but their teacher never told then to use it in implementing speaking subject. When they speak English, they seldom use grammar rule. They just said as they like. The subject can be deleted if assumed known between the addresser and addressee (Ackrapong, 2009).

For their fluency and comprehension, they are good in both of them although requires occasional repetition or rephrasing in every sentence. They could understand what the researcher said but it need more repetition or rephrasing and slow way or using body language to make them get it in every question.

\section{Conclusion}

The results of this research in general revealed that most of the student in Songserm Wittaya School at 4/3 grade, $50 \%$ of them, are good in speaking English through reading English book intensively. So, it concluded that reading intensity is effective on the students' speaking ability in aspect pronunciation, grammar, vocabulary, fluency and comprehension.

\section{References}

Algazoly, A.A.O \& Ahmed, Z.A.U. (2015). Investigating the Effectiveness of Using Intensive Reading in Promoting EFL Learners' Speaking Skills. European Academi Research, 3(7). 8084-8097

Arikunto, Suharsimi. (2013). Prosedur Penelitian Suatu Pendekatan Praktek. Jakarta: Rineka Cipta.
Brown, H.D. 2007. Principle of Language Learning and Teaching. New York: Pearson Education

Darasawang, P., (2007) English Language Teaching and Education in Thailand: A decade of Change. English in Southeast Asia: Varieties, Literacies and Literatures Newcastle D. Prescott (ed.) Cambridge Scholars Publishing pp. 187-204.

Harmer,J. (1998). How to teach English. England: Pearson education.

Hughes, A. 2003. Testing for Language Teachers Second Edition. New York: Cambridge University Press.

Khamkhien, Attapol. 2010. Thai Learners' English Pronunciation Competence: Lesson Learned from Word Stress Assignment. Thailand Kasetsart University

Nunan, D. (1991). Language Teaching Methodology. Macquarie University.

Thep-Ackrapong, T. (2009). Teaching English in Thailand : An Uphill Battle.

Thornbury,S. (2005). How to teach speaking. England: Pearson Education.

Wiriyachitra, A. English language learning and teaching in Thailand in this decade. (n.d.). Retrieved April 9, 2010 from http://www. apecknowledgebank.org 